\title{
Antibacterial Activity of Pipemidic Acid ions-MgFeAl Layered Double Hydroxide Hybrid Against $E$. coli and $S$. typhi
}

\author{
Alejandra Santana-Cruz, ${ }^{1}$ Jorge Luis Flores-Moreno,,${ }^{*} 1$ Roberto Guerra-González ${ }^{2}$ \\ and María de Jesús Martínez-Ortiz ${ }^{3}$ \\ 1 Departamento de Ciencias Básicas, Universidad Autónoma Metropolitana-Azcapotzalco. Av. San Pablo 180, Col. Reynosa \\ Tamaulipas, C.P. 02200, México D.F., México. \\ 2 Universidad Michoacana de San Nicolás de Hidalgo, Facultad de Ingeniería Química, Avenida Francisco J. Múgica s/n \\ Ciudad Universitaria. C.P. 58030, Morelia, Michoacán, México. \\ 3 Instituto Politécnico Nacional, ESIQIE, Avenida IPN UPALM Edificio 7, Zacatenco, 07738 México D.F., México. \\ * Corresponding author: Departamento de Ciencias Básicas, Universidad Autónoma Metropolitana-Azcapotzalco. \\ Av. San Pablo 180, Col. Reynosa Tamaulipas, C.P. 02200, México D.F. \\ email: jflores@correo.azc.uam.mx, Tel: +52 55-53189000 ext. 2233.
}

Received January 15 ${ }^{\text {th }}, 2016$; Accepted April $4^{\text {th }}, 2016$.

\begin{abstract}
An anion exchange process was used to prepare pipemidic acid-MgFeAl composite from $\mathrm{MgFeAl}-\mathrm{Cl}$ layered double hydroxide as inorganic matrix. The obtained hybrid material contains pipemidic acid anions as well as, in a less extent; carbonate and chloride species in its interlayer space. The antibacterial properties were evaluated against E. coli and S. typhi strains through dilution broth method. $\mathrm{MgFeAl}-\mathrm{Cl}$ matrix resulted to be completely inactive against two bacteria, while MgFeAl-PIP composite killed all colonies of $E$. coli after 90 min of exposure and showed a good activity to kill S. typhi bacteria at times as short as $120 \mathrm{~min}$.

Key words: layered double hydroxide; pipemidic acid; hybrid material; intercalation; antibacterial activity.
\end{abstract}

\section{Introduction}

The synthesis of hybrid inorganic-organic systems for human health has received considerable attention. The interest focuses on the synergistic properties, effects and new potential uses. In particular, hybrid materials prepared by intercalation of bioactive molecules into the galleries of layered double hydroxides (LDHs) result in a wide spectrum of versatile materials [1,2]. The application field of these composites depends on the nature of the intercalated anion, thus different LDHs have been used as guests for nonsteroidal anti-inflammatory drugs $[3,4]$, sunscreen agents [5-7], molecules with antioxidant properties [8,9], anticancer drugs [10-12], antibiotics [13-16], and even for DNA and genes [17-19]. In this sense, many efforts have been made aiming to protect the bioactive molecules from degradation, or to enhance the bioavailability and release properties.

Layered double hydroxides belong to a family of interesting inorganic matrices, represented by the general formula $\left[\mathrm{M}_{1-x}^{2+} M_{x}^{3+}(\mathrm{OH})_{2}\right] A_{x / n}^{n-} \cdot m \mathrm{H}_{2} \mathrm{O}$, where $\mathrm{M}^{2+}$ and $\mathrm{M}^{3+}$ are cations,
Resumen. Se preparó el material híbrido ácido pipemídico-MgFeAl por intercambio iónico partiendo del hidróxido doble laminar $\mathrm{MgFeAl}-\mathrm{Cl}$, usado como matriz inorgánica receptora. El material híbrido obtenido contiene en su región interlaminar aniones del ácido pipemídico, así como también, en menor medida; iones carbonato y cloruro que no fueron intercambiados. Las propiedades antibacteriales contra cepas de $E$. coli y $S$. typhi fueron evaluadas mediante el método de dilución en caldo. La matriz inorgánica de partida $\mathrm{MgFeAl}-\mathrm{Cl}$ no presentó actividad antibacterial alguna; sin embargo, el material híbrido MgFeAl-PIP eliminó la totalidad de las colonias de E. coli luego de 90 min de exposición y presentó buena actividad contra bacterias de $S$. typhi después de $120 \mathrm{~min}$.

Palabras clave: hidróxido doble laminar; ácido pipemídico; material híbrido; intercalación; actividad antibacterial.

and $A$ represents either inorganic or organic anions [20,21]. The LDH structure is based on $\mathrm{Mg}(\mathrm{OH})_{6}$ octahedral units sharing edges in order to form $\mathrm{Mg}(\mathrm{OH})_{2}$ brucite-like layers. The octahedral units may contain either divalent $\left(\mathrm{Mg}^{2+}, \mathrm{Ni}^{2+}, \mathrm{Zn}^{2+}\right.$, $\mathrm{Cu}^{2+}, \mathrm{Co}^{2+}$, etc.) or trivalent cations $\left(\mathrm{Al}^{3+}, \mathrm{Fe}^{3+}, \mathrm{Ga}^{3+}, \mathrm{Cr}^{3+}\right.$, etc.) resulting in positively charged sheets. Electroneutrality of the system requires the presence of anions and water molecules occupying the interlayer region, leading to the stacking of the double hydroxide layers.

Pipemidic acid (PA), 8-Ethyl-5-oxo-2-piperazin-1-yl-5,8dihydropyrido[2,3-d]pyrimidine-6-carboxylic acid (Scheme 1), is a derivative of piromidic acid. It is active against gram-negative bacteria as well as some gram-positive bacteria, but it is active against resistant bacteria to piromidic acid and nalidixic acid.

This work deals with synthesis of a hybrid material through the intercalation of pipemidic acid anions into galleries of $\mathrm{MgFeAl} \mathrm{LDH}$. The aim was to study their properties as antibacterial agent against $E$. coli and $S$. typhi strains. 


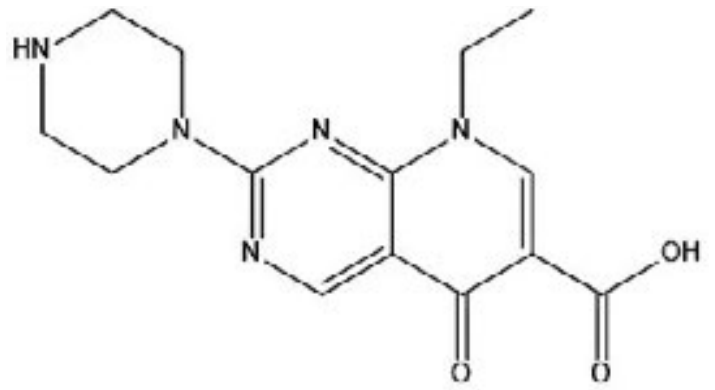

Scheme 1. Chemical structure of pipemidic acid.

\section{Experimental}

\section{Sample Preparation}

The pristine $\mathrm{MgFeAl}-\mathrm{CO}_{3}$, containing carbonate ions in the interlayer region, was synthetized by conventional coprecipitation method under high supersaturation conditions [22]. A $1 \mathrm{M} \mathrm{Mg}^{2+}$, $\mathrm{Al}^{3+}$, and $\mathrm{Fe}^{3+}$ solution was prepared by dissolving the corresponding nitrates salts in deionized water. The following molar ratios were used, $\mathrm{Mg}^{2+} /\left(\mathrm{Fe}^{3+}+\mathrm{Al}^{3+}\right)=3, \mathrm{Al}^{3+} / \mathrm{Fe}^{3+}=3$.6. Separately, a $1 \mathrm{M}$ aqueous solution containing $\mathrm{Na}_{2} \mathrm{CO}_{3}$ and $\mathrm{KOH}$ was prepared. The alkaline solution was added dropwise under vigorous stirring to the metallic solution until $\mathrm{pH}=9$ was reached. The resulting suspension was then aged at $80^{\circ} \mathrm{C}$ for $16 \mathrm{~h}$. At the end of aging, the solid was centrifuged and washed several times with deionized water. Finally, the solid was dried overnight at $120^{\circ} \mathrm{C}$ in an oven yielding the sample named $\mathrm{MgFeAl}-\mathrm{CO}_{3}$.

The MgFeAl-Cl LDH was prepared by suspending the $\mathrm{MgFeAl}-\mathrm{CO}_{3}$ sample in a $0.1 \mathrm{M}$ solution of $\mathrm{NaCl}$. The above suspension was then titrated with $\mathrm{HCl} 0.1 \mathrm{M}$ at $\mathrm{pH}=5$. The resulting solid was centrifuged and washed several times with $\mathrm{CO}_{2}$-free deionized water. The dried solid was stored under vacuum before using.

The intercalated MgFeAl-PIP sample (PIP are pipemidic acid anions) was synthetized by an anion exchange reaction [23]. Pipemidic acid is nearly insoluble in water, thus, to generate a soluble sodium salt, a suspension of pipemidic acid ( $2.8 \mathrm{mmol}$ in $25 \mathrm{~mL}$ of $\mathrm{CO}_{2}$-free deionized water) was reacted with the stoichiometric amount of $\mathrm{NaOH}$ and the final $\mathrm{pH}$ was adjusted to 9. The resulting solution was bubbled with argon before adding MgFeAl-Cl LDH (molar ratio PIP/ $/ \mathrm{M}^{3+}=2$ ). The bubbling was maintained for $1 \mathrm{~h}$. Then, the system was sealed under argon. After seven days of stirring, the MgFeAl-PIP was then separated by centrifugation, washed several times with warm $\mathrm{CO}_{2}$-free deionized water, dried at $80{ }^{\circ} \mathrm{C}$ overnight and finally stored under vacuum.

\section{Antibacterial activity}

The Escherichia coli ATCC® 14028 and Salmonella typhi ATCC ${ }^{\circledR} 25922$ strains were supplied from the Laboratorio
Estatal de Salud Pública de Michoacán. The antibacterial activity of the pristine MgFeAl-Cl LDH and the MgFeAl-PIP composite, against both pathogenic bacteria, was evaluated by agar well diffusion method, according to the procedure previously reported [24-26]. The Minimum Inhibitory Concentration (MIC), defined as the lowest concentration of a particular antibiotic where the absence of visible growth is recorded, was also determined on plates of agar dilution and broth dilution assays. Similar techniques were used to determine the Minimum Bactericidal Concentration (MBC). The MBC is defined as the lowest concentration of an antibacterial agent needed to kill a particular bacterium. Both, agar dilution and broth dilution assays provided similar MIC and MBC values. Both cultures were grown and maintained in tripticaseine broth medium. A starter culture of each strain was inoculated with fresh colonies and then incubated for $24 \mathrm{~h}$ in tripticaseine medium, the inoculum consisted of $10^{9}$ bacteria $/ \mathrm{mL}$. Fresh medium was inoculated in tests tubes with the starter culture and grown at $35.5^{\circ} \mathrm{C}$ under continuous stirring at $30 \mathrm{rpm}$. $\mathrm{MgFeAl}-\mathrm{Cl}$ or $\mathrm{MgFe}-$ Al-PIP were added to bacterial cultures at an average $\mathrm{MBC}$, previously determined for each material. Then, samples were taken at different intervals of time and seeded in Petri dishes previously loaded with $30 \mathrm{~mL}$ of selective agar. Finally, the dishes were incubated at $35.5{ }^{\circ} \mathrm{C}$ under aerobic conditions and the number of surviving colonies was determined. As a control, a plate was inoculated without bactericide material. All the materials were sterilized during experiments with bacteria.

\section{Characterization}

Powder X-ray diffraction (PXRD) patterns were recorded using $\mathrm{CuK}_{\alpha 1}(\lambda=1.5406 \AA)$ on a Philips X'Pert instrument operating at $45 \mathrm{kV}$ and $45 \mathrm{~mA}$ in the $2 \theta$ range of $4-80^{\circ}$.

Infrared spectra were recorded in the range of 4000$400 \mathrm{~cm}^{-1}$ using an FTIR Nicolet Magna IR 750 infrared spectrometer. Samples were diluted with $\mathrm{KBr}$ and then pressed to form discs.

\section{Results and discussion}

PXRD patterns of MgFeAl-Cl LDH and MgFeAl-PIP composite are given in Fig. 1 and the unit cell $c$ parameters are shown in Table 1.

Table 1. The unit cell $c$ parameters obtained for pristine $\mathrm{MgFeAl}-\mathrm{Cl}$ LDH and MgFeAl-PIP composite.

\begin{tabular}{lcc}
\hline \multicolumn{1}{c}{ Sample } & MgFeAl-Cl & MgFeAl-PIP \\
\hline $\boldsymbol{d}_{\mathbf{0 0 3}}(\boldsymbol{\AA})$ & 7.80 & 14.13 \\
$\boldsymbol{d}_{\mathbf{0 0 6}}(\boldsymbol{\AA})$ & 3.92 & 7.04 \\
${\text { Lattice parameter } \boldsymbol{c}^{\boldsymbol{a}}(\AA)}$ & 23.40 & 42.39 \\
\hline
\end{tabular}

${ }^{\text {a }}$ The unit cell $c$ parameter was calculated according to $c=3 \mathrm{~d}_{003}$ 
The XRD reflections of the pristine $\mathrm{MgFeAl}-\mathrm{Cl} \mathrm{LDH}$ are attributed to hydrotalcite structure (JCPDS 22-700) and confirm the formation of a layered structure with a basal spacing of $7.80 \AA$. This value agrees well with those reported for MgFeAl-Cl LDH with similar composition [27,28]. Thus, the sharp peak at $2 \theta=11.33^{\circ}$ corresponds to the (003) plane of the hexagonal structure with rhombohedral symmetry. The position of the (003) reflection depends on the number, orientation and nature of anions hosted in the interlayer region. The (003) peak for the MgFeAl-PIP composite is observed at $2 \theta=6.25^{\circ}$ $(14.13 \AA$ ). . The increase of the interlayer distance from 7.80 to $14.13 \AA$ indicates the effective intercalation of the PIP anions. Thus, as a result of the increase in the basal spacing after exchange, the lattice structure of LDH expanded to the c-axis direction. As the brucite-like layer thickness is $4.8 \AA$ [29], the gallery height can be estimated to be $9.33 \AA$ for MgFeAl-PIP. This gallery height seems to be small to allow hosting such a big anion molecule. Such dimension can be only explained assuming that the intercalated anions molecules are arranged in a monolayer with a tilted orientation toward the brucite-like sheets. Nevertheless, the peaks observed near to $2 \theta=11.33^{\circ}$, and $22.89^{\circ}$ (Fig. 1b) indicate that the exchange of chloride anions by pipemidic acid anions was incomplete. Additionally, the small peak at $2 \theta=9.75^{\circ}$ might be due to intercalation of some pipemidic acid anions with the main axis oriented parallel to the layers of the LDH. It is worth mentioning that none reflection attributable to the pipemidic acid sodium salt was observed. In fact, XRD analysis of the pipemidic acid sodium salt (not included) showed the presence of a completely amorphous phase. However, as Fig. $1 \mathrm{~b}$ indicates, XRD pattern of the MgFeAl-PIP hybrid material is not a combination of the XRD patterns of the pristine $\mathrm{MgFeAl}-\mathrm{Cl} \mathrm{LDH}$ and the pipemidic acid sodium salt, which indicates that, indeed, the intercalation of the pipemidic acid anions was successful.

The FTIR spectra for MgFeAl-Cl LDH and MgFeAl-PIP composite are shown in Fig. 2. It is known that pipemidc acid

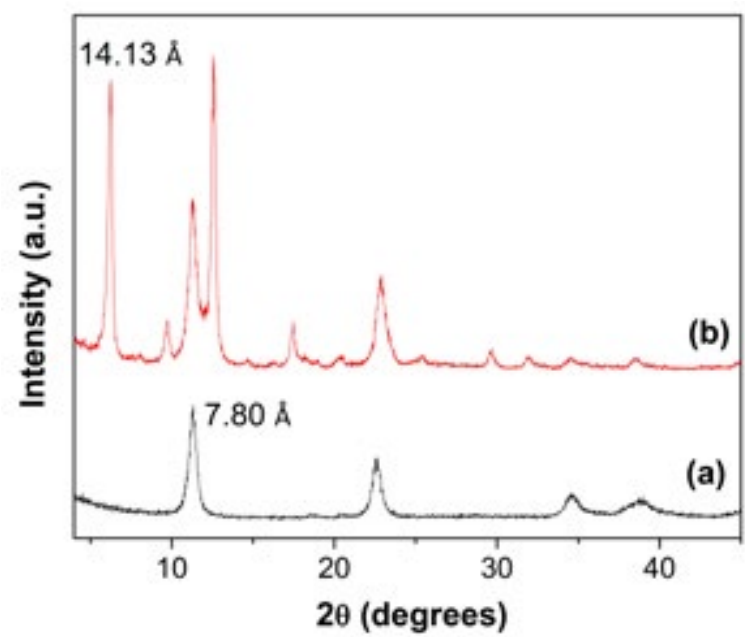

Fig. 1. Powder X-ray diffraction of (a) MgFeAl-Cl LDH and (b) MgFeAl-PIP composite. do not show a $v(\mathrm{C}=\mathrm{O})$ absorption because the carboxylic group is deprotonated and the molecule exists as a zwitterion [30,31]. Instead, two characteristic bands in the range of $1650-1510 \mathrm{~cm}^{-1}$ and $1400-1280 \mathrm{~cm}^{-1}$ are typical for similar ionic carboxylates[32]. These bands are attributable to asymmetrical and symmetrical stretching vibrations of $\mathrm{COO}^{-}$group, respectively. The FTIR spectrum (not shown) of the pipemidic acid shows two strong bands at 1640 and $1618 \mathrm{~cm}^{-1}$ which are assigned to the carbonyl ring group and to the asymmetrical stretching vibrations of $\mathrm{COO}^{-}$group, respectively. The pipemidic acid sodium salt (for clarity not shown) shows a very similar FTIR spectrum to that of pipemidic acid, confirming that the band at $1640 \mathrm{~cm}^{-1}\left(1633 \mathrm{~cm}^{-1}\right.$ for the sodium salt) belongs to the stretching vibrations of $\mathrm{COO}^{-}$group.

For both MgFeAl-Cl LDH (Fig. 2a) and MgFeAl-PIP composite (Fig. 2b), the broad absorption band around $3500 \mathrm{~cm}^{-1}$ is due to $\mathrm{O}-\mathrm{H}$ stretching vibration of the hydroxyl groups conforming the brucite-like layers and water in the interlaminar region. The $\mathrm{O}-\mathrm{H}$ bending vibration of the interlayer water is observed at $1637 \mathrm{~cm}^{-1}$. Besides, MgFeAl-Cl LDH exhibits two bands situated at 1384 and $1364 \mathrm{~cm}^{-1}$ which can be ascribed to $v_{3}$ modes of the carbonate ion.

This indicates that a scarce amount of $\mathrm{CO}_{3}^{2-}$ ions remained in the interlayer region after anion exchange process; nevertheless, none reflection ascribed to the intercalation of $\mathrm{CO}_{3}^{2-}$ ions could be observed by XRD. In fact, according to some reports, $\mathrm{MgAl}-\mathrm{CO}_{3}$ layered double hydroxide exhibits a broad band centered at about $1364 \mathrm{~cm}^{-1}$ assigned to interlayered carbonate anions. After deconvolution, these band decomposes in two components situated a 1388 and $1364 \mathrm{~cm}^{-1}$, attributed to $v_{3^{-}}$ $\mathrm{CO}_{3}^{2-}$ modes. The presence of a single band or a two-split band depends on the symmetry of the $\mathrm{CO}_{3}^{2-}$ ion [33-35].

As a consequence of the antibiotic molecule intercalation, the MgFeAl-PIP composite shows a rather complex FTIR spectrum composed by a combination of IR bands belonging to the layered phase and to the antibiotic molecule. The band at

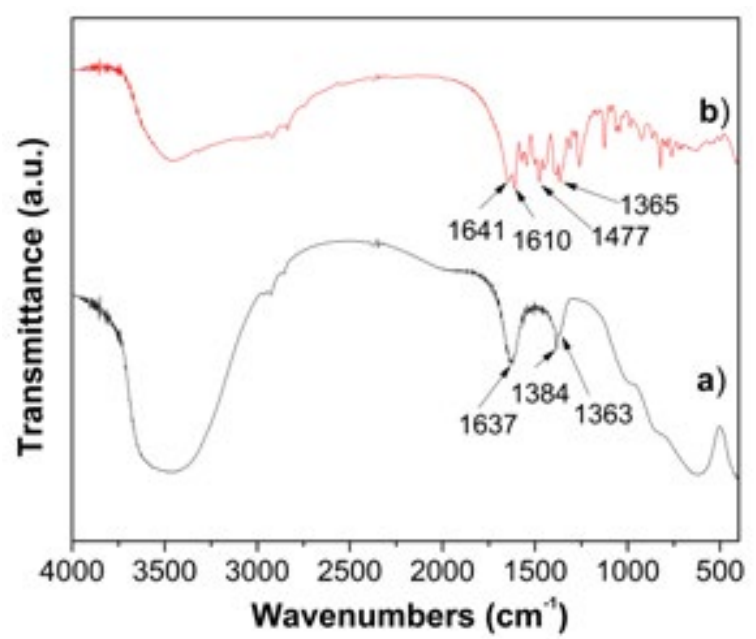

Fig. 2. FTIR spectra of (a) MgFeAl-Cl LDH and (b) MgFeAl-PIP composite. 
$1641 \mathrm{~cm}^{-1}$ is ascribed to the carbonyl ring group, while the band at $1610 \mathrm{~cm}^{-1}$ belongs to the asymmetrical stretching vibrations of $\mathrm{COO}^{-}$group.

Results from both, XRD and FTIR analysis, confirm the intercalation of the antibiotic molecule into the galleries of the $\mathrm{MgFeAl}-\mathrm{LDH}$.

The MIC and the MBC values are reported in Table 2. The results indicate that $\mathrm{MgFeAl}-\mathrm{PIP}$ hybrid material is slightly more effective against $E$. coli than $S$. typhi. The $\mathrm{MgFeAl}-\mathrm{Cl}$ and $\mathrm{MgFeAl}-\mathrm{NO}_{3}$ (included as a reference) did not show antimicrobial activity. As a comparison, the MIC of pure pipemidic acid were found to be $1.56 \mu \mathrm{g} / \mathrm{mL}$ and $3.13 \mu \mathrm{g} / \mathrm{mL}$ against E. coli and S. typhi, respectively, suggesting that PA is, in fact, twice more active for E. coli than $S$. typhi [36].

Table 2. The MIC and the MBC values of layered and composite materials against E. coli (Gram negative) and S. typhi (Gram negative) bacteria.

\begin{tabular}{lcccc}
\hline \multirow{2}{*}{ Material } & \multicolumn{2}{c}{ MIC $(\mathrm{mg} / \mathrm{mL})^{\mathrm{a}, \mathrm{b}}$} & \multicolumn{2}{c}{ MBC $(\mathrm{mg} / \mathrm{mL})^{\mathrm{a}, \mathrm{b}}$} \\
\cline { 2 - 5 } & E. coli & S. typhi & E. coli & S. typhi \\
\hline $\mathrm{MgFeAl} \mathrm{CO}_{3}$ & N.A. & N.A. & N.A. & N.A. \\
${\mathrm{MgFeAl}-\mathrm{NO}_{3}}$ & N.A. & N.A. & N.A. & N.A. \\
$\mathrm{MgFeAl}-\mathrm{Cl}$ & N.A. & N.A. & N.A. & N.A. \\
$\mathrm{MgFeAl}-\mathrm{PIP}$ & 3.5 & 4.5 & 4.0 & 5.0 \\
\hline
\end{tabular}

${ }^{\mathrm{a}}$ N.A. No Activity, ${ }^{\mathrm{b}}$ on the basis of the mass of material.

In order to study the kinetics of the antimicrobial action of MgFeAl-LDHs (as reference) and MgFeAl-PIP composite a time-kill test at concentrations corresponding to the $\mathrm{MBC}$ value (Table 2) was achieved. As shown in (Fig. 3), E. coli bacteria multiply rapidly with time in presence of carbonate and nitrate containing MgFeAl-LDH, the number of colonies duplicated after 20 and $93 \mathrm{~min}$, respectively, confirming null antimicrobial activity. As to $\mathrm{MgFeAl}-\mathrm{Cl} \mathrm{LDH}$, it behaves almost as a bacteriostatic material during time. In this regard, it has been proven that other common LDHs such as $\mathrm{ZnAl}-\mathrm{CO}_{3}[37,38], \mathrm{MgAl}-\mathrm{CO}_{3}$ and $\mathrm{MgAl}-\mathrm{NO}_{3}$ [39] do not exhibit any antibacterial activity against E. coli. Same conclusion was established for MgAl$\mathrm{NO}_{3}$ against $S$. aureus [40]. This demonstrates that LDHs do not exhibit any antibacterial characteristic by themselves, even if they contain chloride anions in their interlayer region. Finally, based on the results in Fig. 3, it is clear that the effect of the inorganic compensating anion $\left(\mathrm{CO}_{3}^{2-}, \mathrm{NO}_{3}^{-}\right.$or $\left.\mathrm{Cl}^{-}\right)$on the growth rate is quite different. In contrast, the MgFeAl-PIP hybrid material showed a total fungicidal effect and none bacteria remain alive after $30 \mathrm{~min}$. It seems noticeable that antibacterial properties of the pipemidic acid molecule were preserved after intercalation into the LDH. Thus, the hybrid material resulted in an efficient antibacterial system against $E$. coli.

On the other hand, Fig. 4 shows results of kinetics of antibacterial tests for MgFeAl-LDHs and MgFeAl-PIP composite against S. typhi. As observed for E. coli in Fig. 3, none of the inorganic anion containing LDHs showed antibacterial action.

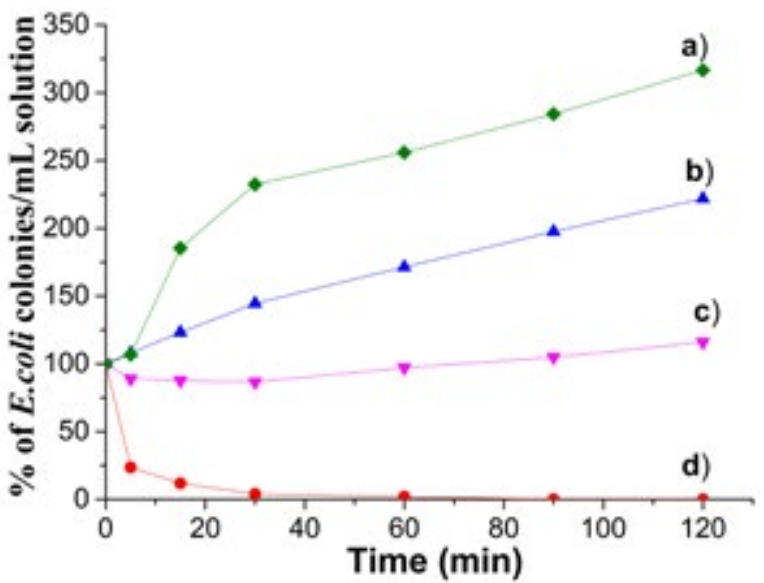

Fig. 3. Percentage of $E$. coli colonies surviving in culture media in presence of a) $\mathrm{MgFeAl}-\mathrm{CO}_{3} \mathrm{LDH}$, b) $\mathrm{MgFeAl}-\mathrm{NO}_{3} \mathrm{LDH}$ c)MgFe$\mathrm{Al}-\mathrm{Cl} \mathrm{LDH}$ and d) MgFeAl-PIP hybrid material. Each material was evaluated at $\mathrm{MBC}$.

In this case, $\mathrm{MgFeAl}-\mathrm{Cl}$ allows rapid development of colonies of $S$. typhi. Conversely, MgFeAl-PIP hybrid material showed good activity to eliminate bacteria, as only $12 \%$ of colonies survived after $90 \mathrm{~min}$ of exposure. As previously pointed out by results of $\mathrm{MIC}$ and $\mathrm{MBC}$ values, $\mathrm{MgFeAl}-\mathrm{PIP}$ is less active to eliminate $S$. typhi than $E$. coli pathogens. These results are in good agreement with the data previously reported for the antibacterial activity of supported gold nanoparticles against $E$. coli and $S$. typhi [24]. Independently of the bactericide material, it is harder to kill $S$. typhi than E. coli because the first one has a very complex and resistant plasmatic membrane [41].

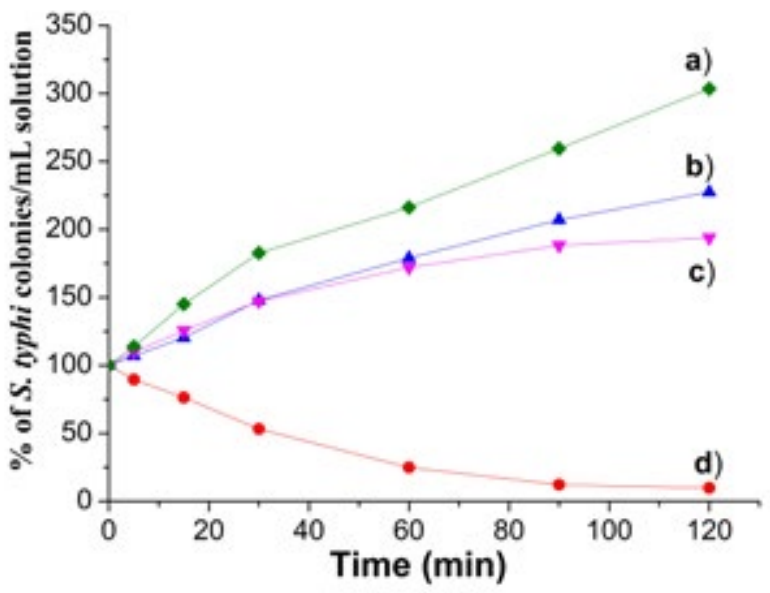

Fig. 4. Percentage of $S$. typhi colonies surviving in culture media in presence of a) $\mathrm{MgFeAl}-\mathrm{CO}_{3} \mathrm{LDH}$, b) $\mathrm{MgFeAl}-\mathrm{NO}_{3} \mathrm{LDH}$ c) $\mathrm{MgFe}-$ $\mathrm{Al}-\mathrm{Cl} \mathrm{LDH}$ and d) MgFeAl-PIP hybrid material. Each material was evaluated at $\mathrm{MBC}$. 


\section{Conclusions}

MgFeAl-PIP composite was prepared by exchanging pipemidic acid anions into the interlayer space of MgFeAl-Cl LDH. The exchange degree was not complete, as some $\mathrm{Cl}^{-}$anions remained in the interlayer space. The gallery height estimated to be $9.33 \AA$ Á suggested that pipemidic acid anions were intercalated as a monolayer in a tilted mode. However, some molecules were probably intercalated parallel to brucite-like sheets. MgFeAl-PIP hybrid showed efficient antibacterial activity against E. coli and $S$. typhi. The pristine MgFeAl LDH chosen in this work resulted to be a very good biocompatible inorganic host, as it cares not killing bacteria by itself, but it allows driving the release of biologically active molecules into the media growth with time. MgFeAl-PIP composite eliminated all colonies of E. coli after $90 \mathrm{~min}$ of exposure and showed good activity to eliminate $S$. typhi bacteria at times as short as $120 \mathrm{~min}$.

\section{Acknowledgements}

ASC gratefully wishes to acknowledge CONACyT for financial support through a Master fellowship.

\section{References}

1. Costantino, U.; Nocchetti, M.; Sisani, M.; and Vivani, R. Zeitschrift für Krist. 2009, 224, 273-281.

2. Del Hoyo, C. Appl. Clay Sci. 2007, 36, 103-121.

3. Ambrogi, V.; Fardella, G.; Grandolini, G.; and Perioli, L. Int. J. Pharm. 2001, 220, 23-32.

4. Del Arco, M.; Fernández, A.; Martin, C.; and Rives, V. Appl. Clay Sci. 2007, 36, 133-140.

5. Perioli, L.; Ambrogi, V.; Bertini, B.; Ricci, M.; Nocchetti, M.; Latterini, L.; and Rossi, C. Eur. J. Pharm. Biopharm. 2006, 62, 185-193.

6. Perioli, L.; Ambrogi, V.; Rossi, C.; Latterini, L.; Nocchetti, M.; and Costantino, U. J. Phys. Chem. Solids 2006, 67, 1079-1083.

7. Perioli, L.; Nocchetti, M.; Ambrogi, V.; Latterini, L.; Rossi, C.; and Costantino, U. Microporous Mesoporous Mater. 2008, 107, 180-189.

8. Lima, E.; Flores, J.; Cruz, A. S.; Leyva-Gómez, G.; and Krötzsch, E. Microporous Mesoporous Mater. 2013, 181, 1-7.

9. Rossi, C.; Schoubben, A.; Ricci, M.; Perioli, L.; Ambrogi, V.; Latterini, L.; Aloisi, G. G.; and Rossi, A. Int. J. Pharm. 2005, 295, 47-55.

10. Tyner, K. M.; Schiffman, S. R.; and Giannelis, E. P. J. Control. Release 2004, 95, 501-514.

11. Pang, X.; Ma, X.; Li, D.; and Hou, W. Solid State Sci. 2013, 16, 71-75.

12. Chakraborty, M.; Dasgupta, S.; Sengupta, S.; Chakraborty, J.; Ghosh, S.; Ghosh, J.; Mitra, M. K.; Mishra, A.; Mandal, T. K.; and Basu, D. Ceram. Int. 2012, 38, 941-949.

13. Ryu, S.-J.; Jung, H.; Oh, J.-M.; Lee, J.-K.; and Choy, J.-H. J. Phys. Chem. Solids 2010, 71, 685-688.
14. San Román, M. S.; Holgado, M. J.; Salinas, B.; and Rives, V. Appl. Clay Sci. 2012, 55, 158-163.

15. Wang, J.; Liu, Q.; Zhang, G.; Li, Z.; Yang, P.; Jing, X.; Zhang, M.; Liu, T.; and Jiang, Z. Solid State Sci. 2009, 11, 1597-1601.

16. Trikeriotis, M.; and Ghanotakis, D. F. Int. J. Pharm. 2007, 332, 176-184.

17. Choy, J.; Kwak, S.; Jeong, Y.; and Park, J. Angew. Chem. Int. Ed. Engl. 2000, 39, 4041-4045.

18. Choy, J.-H.; Kwak, S.-Y.; Park, J.-S.; Jeong, Y.-J.; and Portier, J. J. Am. Chem. Soc. 1999, 121, 1399-1400.

19. Choy, J.-H.; Park, J.-S.; Kwak, S.-Y.; Jeong, Y.-J.; and Han, Y.-S. Mol. Cryst. Liq. Cryst. Sci. Technol. Sect. A. Mol. Cryst. Liq. Cryst. 2000, 341, 425-429.

20. Evans, D. G.; and Slade, R. C. T. In Layered Double Hydroxides; Duan, X.; and D. G. Evans, Eds.; Springer Berlin Heidelberg, 2006; pp. 1-87.

21. Cavani, F.; Trifirò, F.; and Vaccari, A. Catal. Today 1991, 11, 173-301.

22. Auer, S.; Grunwaldt, J.; Köppel, R.; and Baiker, A. J. Mol. Catal. A Chem. 1999, 139, 305-313.

23. Miyata, S. Clays Clay Miner. 1983, 31, 305-311.

24. Guerra, R.; Lima, E.; and Guzmán, A. Microporous Mesoporous Mater. 2013, 170, pp. 62-66.

25. Guerra, R.; Lima, E.; Viniegra, M.; Guzmán, A.; and Lara, V. Microporous Mesoporous Mater. 2012, 147, 267-273.

26. Lima, E.; Guerra, R.; Lara, V.; and Guzmán, A. Chem. Cent. J. 2013, 7, 11 .

27. Li, S.-P.; Hou, W.-G.; Han, S.-H.; Li, L.-F.; and Zhao, W.-A. J. Colloid Interface Sci. 2003, 257, 244-249.

28. Del Arco, M.; Fernández, A.; Martin, C.; and Rives, V. Appl. Clay Sci. 2009, 42, 538-544.

29. Miyata, S. Clays Clay Miner. 1975, 23, 369-375.

30. Fonseca, I.; Martínez-Carrera, S.; and García-Blanco, S. Acta Crystallogr. Sect. C Cryst. Struct. Commun. 1986, 42, 1618-1621.

31. Skrzypek, D.; Szymanska, B.; Kovala-Demertzi, D.; Wiecek, J.; Talik, E.; and Demertzis, M. A. J. Phys. Chem. Solids 2006, 67, 2550-2558.

32. Turel, I. Coord. Chem. Rev. 2002, 232, 27-47.

33. Tanaka, T.; Kameshima, Y.; Nishimoto, S.; and Miyake, M. Anal. Methods 2012, 4, 3925.

34. Kloprogge, J. T.; Krisof, J.; and Frost, R. L. In 12th International Clay Conference; Dominguez, E., Mas, G., \& Cravero, F.; Bahai-Blanca, Argentina, 2001.

35. Kloprogge, J. T.; and Frost, R. L. J. Solid State Chem. 1999, 146, 506-515.

36. Shimizu, M.; Takase, Y.; Nakamura, S.; Katae, H.; and Minami, A. Antimicrob. Agents Chemother. 1975, 8, 132-138.

37. Mishra, G.; Dash, B.; Pandey, S.; and Mohanty, P. P. J. Environ. Chem. Eng. 2013, 1, 1124-1130.

38. Ballarin, B.; Mignani, A.; Mogavero, F.; Gabbanini, S.; and Morigi, M. Appl. Clay Sci. 2015, 114, 303-308.

39. Wang, M.; Hu, Q.; Liang, D.; Li, Y.; Li, S.; Zhang, X.; Xi, M.; and Yang, X. Appl. Clay Sci. 2013, 83-84, 182-190.

40. Ryu, S.-J.; Jung, H.; Oh, J.-M.; Lee, J.-K.; and Choy, J.-H. J. Phys. Chem. Solids 2010, 71, 685-688.

41. Atlas, R. M. Principles of Microbiology; Editorial Mosby: USA, 1995. pp. 43-55. 